\title{
A NOTE ON THE DENSITY DISTRIBUTION OF DRY SNOW
}

\author{
By CHI-HAI LING
}

(Ice Dynamics Project, U.S. Geological Survey, University of Puget Sound, Tacoma, Washington 98416, U.S.A.)

ABSTRACT. A simple mathematical expression for the density distribution of dry snow is described in this note. It compares very well with observations.

RÉsumé. Note sur la densification de la neige sèche. On propose une expression mathématique simple qui rend

Benson (1960) (see also Anderson and Benson, 1963) studied the problem of densification of dry snow and derived a simple formula to describe the density of dry snow as a function of depth. Their formula is very accurate when compared with observation. However, to use it one usually needs to know two coefficients of proportionality for each location, in addition to given values of surface snow density and maximum attainable snow density. (The number of coefficients can be reduced, however, in the case of new snow.) Bader (1963) developed a thecry which also describes very accurately the density distribution of snow, but one needs to know six parameters for each location.

This note describes a simple mathematical expression for the density distribution of dry snow in a way that requires only one free coefficient or none, at the expense of a little accuracy. We assume that, at any specific time, the change of density $d_{\rho}$ in the vertical direction is related to the change of pressure $\mathrm{d} p$ and $\rho_{\mathrm{m}}-\rho$ (Robin, 1958; Herron and Chester, 1980), where $p_{m}$ is the maximum attainable density for the dry snow at a certain location and $\rho$ is the density at a certain depth, by

$$
\mathrm{d} \rho=c\left(\rho_{\mathrm{m}}-\rho\right) \mathrm{d} p
$$

where $c$ is a proportionality constant and the change of pressure is

$$
\mathrm{d} p=-\rho g \mathrm{~d} z
$$

where $z$ is the distance from the snow surface. However, here we assume a more general relationship

$$
\mathrm{d}\left(\rho^{n}\right)=c\left(\rho_{\mathrm{m}}-\rho\right) \mathrm{d} p
$$

where the parameters $n$ and $c$ are determined by comparison with the field data. Here $n$ is a measure of stiffness of the snow and $c$ is a proportionality constant. When $n=2$, the integration of Equations (3) and (2) gives

$$
\left(\rho_{\mathrm{m}}-\rho\right) /\left(\rho_{\mathrm{m}}-\rho_{0}\right)=\mathrm{e}^{-\lambda z}
$$

where $p_{0}$ is the surface density of snow.

Letting $\lambda=1 / L$ where $L$ is a characteristic length scale, we have

$$
\left(\rho_{\mathrm{m}}-\rho\right) /\left(\rho_{\mathrm{m}}-\rho_{0}\right)=\mathrm{e}^{-(z / L)}
$$

or

$$
\left(\rho-\rho_{0}\right) /\left(\rho_{\mathrm{m}}-\rho_{0}\right)=1-\mathrm{e}^{-(z / L)} .
$$

très bien compte de la densification de la neige sèche.

ZUSAMMENFASSUNG. Eine Bemerkung zur Dichteverteilung in trockenem Schnee. Es wird ein einfacher mathematischer Ausdruck für die Verteilung der Dichte in trockenem Schnee mitgeteilt. Er passt sehr gut zu entsprechenden Beobachtungen.

Figures 1 through 4 compare Equation (4) with measurements in dry snow at four locations from Greenland, the Colorado Rockies, and Antarctica, and a combined dimensionless plot is shown in Figure 5. In the case of Antarctic and Greenland snow, the knowledge of a length scale would be enough to calculate the density, whereas for shallow new snow, $L$ may be set equal to one-third the total depth of the snow. Integration of Equation (4)

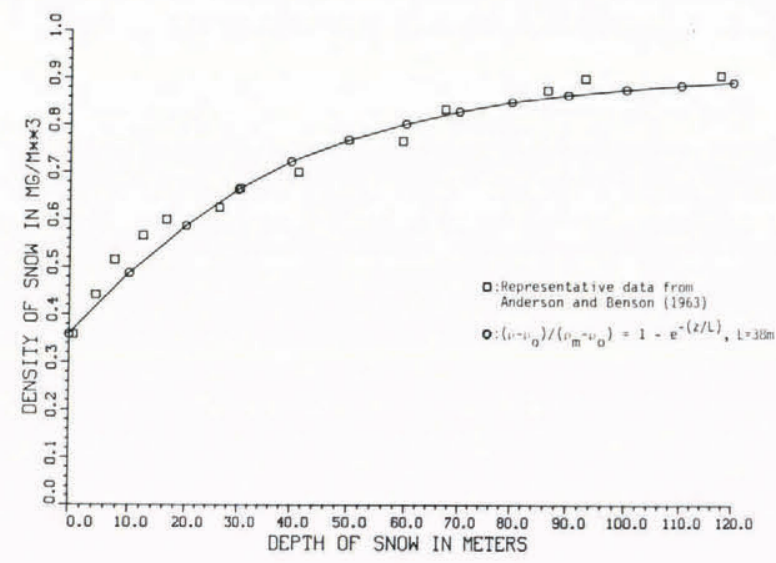

Fig. 1. Snow density versus depth for Station 2, Greenland.

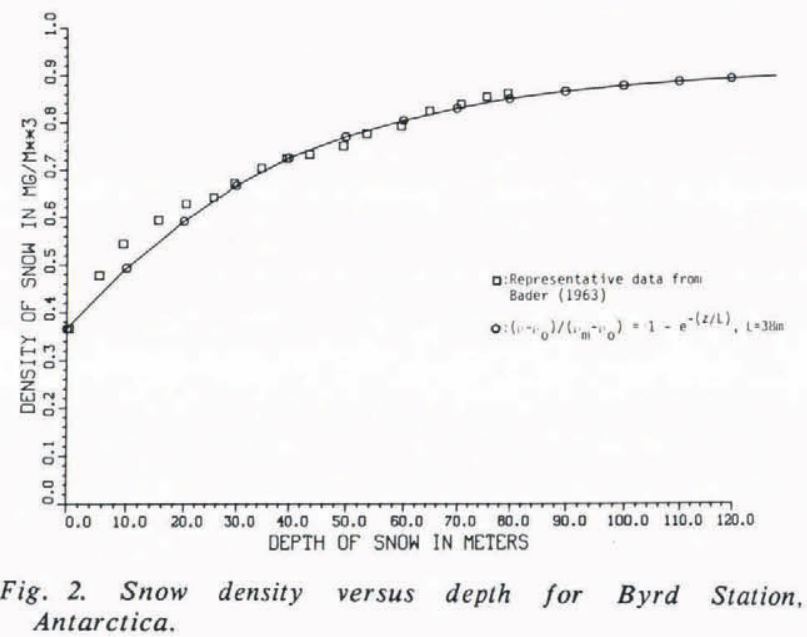




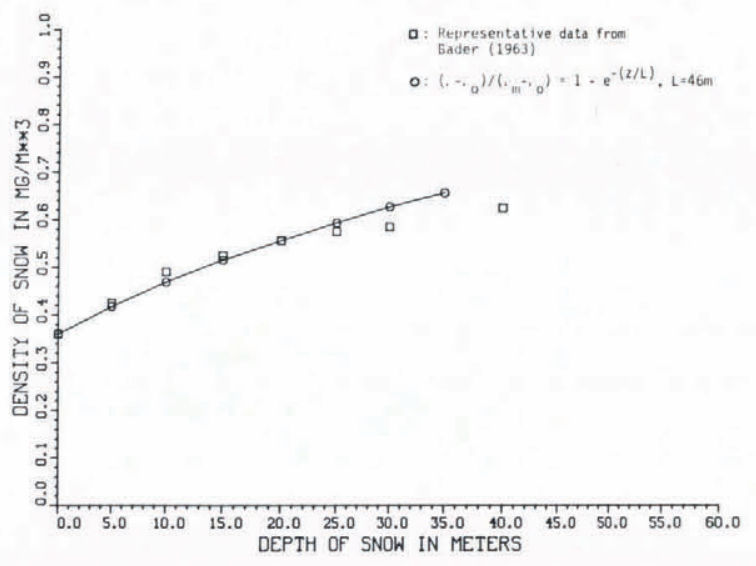

Fig. 3. Snow density versus depth for South Pole.

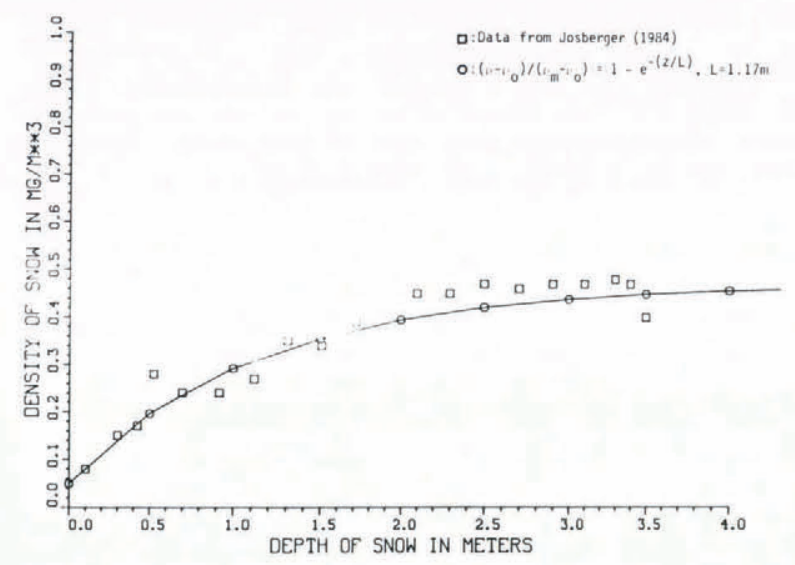

Fig. 4. Snow density versus depth for Tower Station, Colorado; data collected during the winter of 1980; personal communication from E.G. Josberger, 1984.

throughout the depth gives the total mass of dry snow per unit area as

$$
\int_{0}^{h} \rho \mathrm{d} z=\rho_{\mathrm{m}} h-\left(\rho_{\mathrm{m}}-\rho_{0}\right) L\left(1-\mathrm{e}^{-h / L}\right)
$$

and for shallow new snow, this expression reduces to

$$
\int_{0}^{h} \rho \mathrm{d} z=\rho_{\mathrm{m}} h-0.317 h\left(\rho_{\mathrm{m}}-\rho_{0}\right) \text {. }
$$

The curve represented by Equation (4) corresponds quite

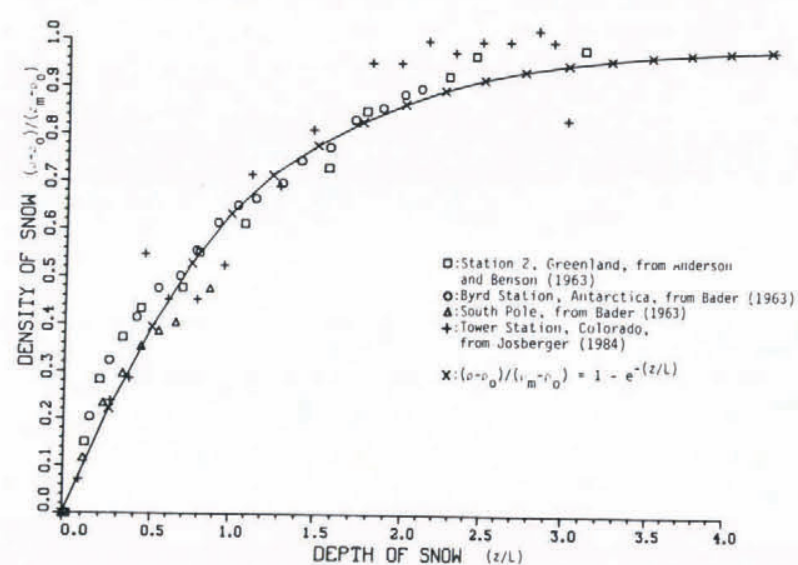

Fig. 5. Snow density versus depth.

well with snow data as shown in Figures 1 through 5 . It is concluded that the non-linear relationship between the change of density and the change of pressure represented by Equation (3) would be a good candidate for use in the density distribution of dry snow.

\section{ACKNOWLEDGEMENTS}

I want to thank E.G. Josberger and S. Hodge for their help in providing recent snow data they collected, and I want to thank W.J. Campbell for his suggestions. I also want to thank Professor C. Benson for his encouragement and help in this work.

\section{REFERENCES}

Anderson, D.L., and Benson, C.S. 1963. The densification and diagenesis of snow. (In Kingery, W, ed Ice and snow; properties, processes, and applications: proceedings of a conference held at the Massachusetts Institute of Technology, February 12-16, 1962. Cambridge, Mass., M.I.T. Press, p. 391-411.)

Bader, H. 1963. Theory of densification of dry snow on high polar glaciers, II. (In Kingery, W.D., ed. Ice and snow; properties, processes, and applications: proceedings of a conference held at the Massachusetts Institute of Technology, February 12-16, 1962. Cambridge, Mass., M.I.T. Press, p. 351-76.)

Benson, C.S. 1962. Stratigraphic studies in the snow and firn of the Greenland ice sheet. U.S. Snow, Ice and Permafrost Research Establishment. Research Report 70.

Herron, M.M., and Langway, C.C., jr. 1980. Firn densification: an empirical model. Journal of Glaciology, Vol. 25, No. 93, p. 373-85.

Robin, G. de Q. 1958. Glaciology. III. Seismic shooting and related investigations. Norwegian-British-Swedish Antarctic Expedition, 1949-52. Scientific Results, Vol. 5. 